\title{
Quantification of Thermotolerant Campylobacter spp. in Frozen Chicken Carcasses
}

\author{
Juliano Borsato-Moysés (I), Sarah Jarschel de Camargo (III), \\ Maristela da Silva do Nascimento (II), Neusely da Silva (II), Valéria \\ Cristina Amstalden Junqueira (II) \\ (I) IBILCE - UNESP - Universidade Estadual Paulista (Campus de São José do Rio Preto), (II) \\ ITAL - Instituto de Tecnologia de Alimentos (Avenida Brasil, 2880 - Campinas, SP), (III) \\ Metrocamp - Veris Metrocamp IBTA (Campinas-SP)
}

\section{Resumo}

Campylobacteriosis, zoonosis caused mainly by thermotolerant

Campylobacter spp., is one of the foodborne diseases more frequent in the world and chicken meat is the most important vehicle of transmission. In this context, we evaluated comparatively the performance of culture media in quantifying this microbial genus in chicken meat. From this, were collected in retail stores from city of Campinas, SP, 30 samples of whole frozen chicken carcasses, of different commercial brands, under sanitary inspection and in the adequate shelf life. The samples were weighed and superficial cleaned (internal and external) for two minutes, being used Buffered Peptone Water (BPW) as diluent, at a ratio of $4 \mathrm{~g}$ of sample per $\mathrm{mL}$ of diluent. The colony counting was conducted according to ISO 10272-2:2006 methodology, with surface plating in two different culture media, Charcoal Cefoperazone Deoxycholate Modified Agar (mCCDA) as a reference medium and the chromogenic CampyFood Agar (CFA), both in duplicate with $250 \mu \mathrm{L}$ inoculum, volume equivalent to $1 \mathrm{~g}$ of sample. Subsequently the morphology and motility were verified and oxidase production tests performed, growth at $41.5^{\circ} \mathrm{C}$ in aerobic and $25^{\circ} \mathrm{C}$ in microaerobic for confirmation of thermotolerant Campylobacter spp. The mCCDA detected the presence of the bacteria in four samples (13\%) with count ranging from $0,3 \log \mathrm{CFU} / \mathrm{g}$ to $0,9 \log \mathrm{CFU} / \mathrm{g}$. The CFA has detected the presence in eight samples $(27 \%)$ with count ranging from

\footnotetext{
Referência:

Juliano Borsato-Moysés, Sarah Jarschel de Camargo, Maristela da Silva do Nascimento, Neusely da Silva, Valéria Cristina Amstalden Junqueira. Quantification of Thermotolerant Campylobacter Spp. in Frozen Chicken Carcasses. In: Anais do $12^{\circ}$ Congresso Latinoamericano de Microbiologia e Higiene de Alimentos - MICROAL 2014 [= Blucher Food Science Proceedings, num.1, vol.1]. São Paulo: Editora Blucher, 2014. DOI 10.5151/foodsci-microal-144
} 
$0,04 \log \mathrm{CFU} / \mathrm{g}$ to $2,1 \log \mathrm{CFU} / \mathrm{g}$. The CFA chromogenic medium was more effective in isolation. The results also showed that these microorganisms survive in frozen chicken carcasses. Due to the importance of this microbial group for global public health, the contamination found in food kept under freezing evidences the need for constant monitoring of these food products.

Palavras-Chave: chicken meat, Campylobacter, culture media, mCCDA, CFA

Agência de Fomento: FAPESP 